\title{
Case Report: Dengue Virus-Triggered Parkinsonism in an Adolescent
}

\author{
Prateek Kumar Panda, ${ }^{1} \dagger$ Indar Kumar Sharawat, ${ }^{1 *} \dagger$ Rishi Bolia, ${ }^{2}$ and Yash Shrivastava ${ }^{2}$ \\ ${ }^{1}$ Pediatric Neurology Division, Department of Pediatrics, All India Institute of Medical Sciences, Rishikesh, India; ${ }^{2}$ Department of Pediatrics, All \\ India Institute of Medical Sciences, Rishikesh, India
}

\begin{abstract}
Dengue fever continues to be an important cause of morbidity and mortality in tropical and subtropical countries. A wide range of neurological manifestations including dengue encephalopathy, Guillain-Barre syndrome, acute disseminated encephalomyelitis, transverse myelitis, cranial nerve palsies, and myositis have been reported following dengue infection. But parkinsonism secondary to dengue virus infection is uncommon, with only three published case reports in adults and one in children. We describe a 13-year-old pre-morbidly normal boy, who presented with bradykinesia, bradyphonia, mask-like facies, and cogwheel rigidity while recovering from uncomplicated DF. He responded favorably to levodopa/carbidopa supplementation and had resolution of symptoms over the next 2 weeks. We also did a comparative review of all published cases of dengue-induced parkinsonism. Post-dengue, parkinsonism is uncommon, and treating clinicians should be aware of this uncommon but treatable neurological complication of a common arboviral infection.
\end{abstract}

\section{INTRODUCTION}

Dengue fever (DF) continues to be an important cause of morbidity and mortality in tropical and subtropical countries. ${ }^{1}$ A wide range of neurological manifestations has been reported following dengue infection. ${ }^{2}$ These include dengue encephalopathy, Guillain-Barre syndrome, acute disseminated encephalomyelitis, transverse myelitis, cranial nerve palsies, and myositis. ${ }^{2}$ As such, neurological complications of dengue infection are quite uncommon. Furthermore, parkinsonism secondary to dengue virus infection is uncommon, with only three published case reports in adults and one in children. ${ }^{3-5}$ We describe a 13-year-old, pre-morbidly normal boy, who developed Parkinsonism after dengue infection. We also did a comparative review of all published cases of dengue-induced parkinsonism in children and adults.

\section{CASE REPORT}

Clinical presentation. A 13-year-old boy, resident of the northern part of India, presented with fever for the past 2 days. The fever was acute onset, high grade (up to $104^{\circ} \mathrm{F}$ ), was associated with chill and rigor, severe malaise, body ache, and erythematous, non-blanching, and nonpruritic rashes over the face and trunk. On laboratory evaluation, he had normal hemoglobin (15.1 gm/dL), decreased total leukocyte count $(2,950 / \mathrm{uL})$, and thrombocytopenia (platelet count-87,000/uL). Because DF was the most common cause of viral illness with thrombocytopenia in the region, the NS1 antigen was tested, and it was found to be positive. Remaining all laboratory investigations were normal. The child did not develop any warning signs, and the fever resolved after 3 days of admission. However, on day 6 of illness, he developed bradyphonia, unclear speech, and gait instability. He also had bradykinesia while trying to perform any purposeful activity like getting up from the bed. Moreover, the next day onward, he developed increased stiffness, more in the legs than in the arms, mainly in

*Address correspondence to Indar Kumar Sharawat, Pediatric Neurology Division, Department of Pediatrics, All India Institute of Medical Sciences, Rishikesh 249203, India. E-mail: sherawatdrindar@ gmail.com

†These authors contributed equally to this work. the form of cogwheel rigidity. He also had mask-like facies and stooped posture while walking. However, he did not have any change in sensorium, focal deficit, behavioral abnormality, resting tremor, or diurnal variation in his symptoms.

Diagnostic evaluation. Magnetic resonance imaging (MRI) of the brain (Figure 1), cerebrospinal fluid (CSF) examination, and electroencephalography were within normal limits. Workup for systemic lupus erythematosus, autoimmune encephalitis, anti-basal ganglia encephalitis, Wilson disease, and other neurometabolic diseases were also noncontributory. The diagnosis of dengue-induced parkinsonism was considered taking into account the clinical and laboratory parameters.

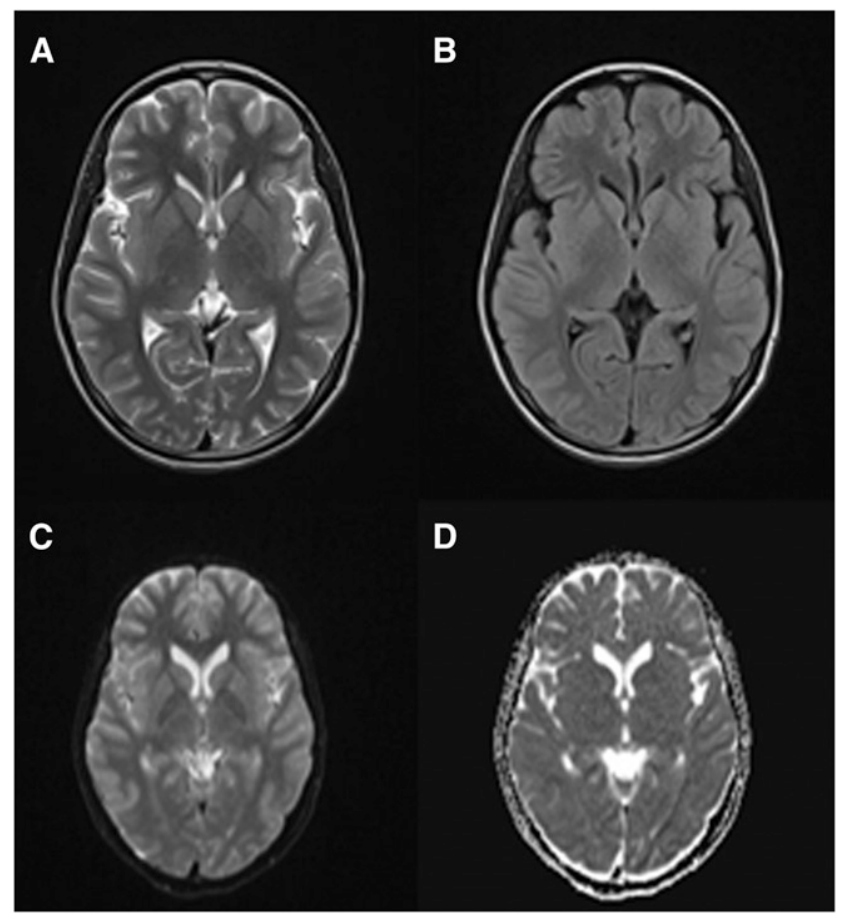

FIGURE 1. Magnetic resonance imaging of the brain of a child with dengue-triggered parkinsonism. T-weighted (A), fluid-attenuated inversion recovery (B), diffusion-weighted (C) sequences, and apparent diffusion coefficient map (D) does not show any basal ganglia or parenchymal abnormalities. 
Management and follow-up. Oral levodopa-carbidopa combination at an escalating dose of $100-200 \mathrm{mg} /$ day in divided doses was administered, and the boy showed a favorable response, with gradual resolution of symptoms over the next 2 weeks. On a regular follow-up at three months, he did not have any abnormality in gait or speech, and his neurological examination was essentially normal.

\section{DISCUSSION}

Dengue fever is an arboviral illness caused by any of the four dengue virus serotypes DENV 1-4. Its primary mode of transmission between humans is by the female Aedes mosquito. The disease is most prevalent in tropical and subtropical regions of the world. Infection with dengue virus may result in symptoms of varying severity, ranging from mild asymptomatic DF to severe DF, with warning signs and potentially lifethreatening dengue hemorrhagic fever and dengue shock syndrome. 1

Neurological complications of dengue are relatively uncommon. Meningoencephalitis, acute disseminated encephalomyelitis, transverse myelitis, ischemic and hemorrhagic strokes, cerebellar syndrome, myositis, peripheral neuritis, Guillain-Barre Syndrome, and optic neuritis have all been reported in various case reports and series from various parts of the world. However, acute onset parkinsonian features triggered by dengue viral infection have uncommonly been reported. ${ }^{3}$
Viruses known to induce parkinsonism or related symptoms include Japanese encephalitis virus, West Nile virus, coxsackie virus, human immunodeficiency virus (HIV), varicella-zoster virus, herpes simplex virus (HSV), Epstein-Barr virus, and cytomegalovirus. ${ }^{6}$ Exact pathophysiology behind any post-viral parkinsonism is yet to be elucidated. Efforts to detect viral particles in the brain or antibodies in the serum or the CSF have been mostly unsuccessful. ${ }^{6}$ Three different pathophysiological processes such as a direct neurotropic invasion, systemic complication, and postinfectious autoimmune phenomenon have been implicated in these complications. ${ }^{6}$ Recent immunohistochemical work in post-viral parkinsonism favors the role of complement proteins and interferons in post-viral encephalitis. ${ }^{6}$

A review of the published literature in "Pubmed," "Google Scholar," and other electronic databases revealed only four cases of parkinsonism triggered by dengue viral infection till now. Among these four cases, only one case reported by Fong et al. ${ }^{4}$ was in the pediatric age-group. A comparison of clinical features of all five cases, including the index case, has been shown in Tables 1 and 2. Interestingly, all affected cases are male, and in all cases, CSF examination was normal. Dengue virus was not isolated by polymerase chain reaction (PCR) in the CSF of any of these cases during parkinsonism. Magnetic resonance imaging brain was also normal in three of four previously reported cases, and only one case showed microinfarcts in basal ganglia.

Most of them had dengue IgG positivity, indicating a history of previous dengue infection too. .,4 $^{3,4}$ is not surprising, as it has been demonstrated that neurological manifestations of

TABLE 1

Comparison of clinical and laboratory parameters in the initial phase of illness (dengue fever)

\begin{tabular}{|c|c|c|c|c|c|}
\hline Variable & Azmin et al. (2013) & Fong et al. (2014) & Bopethha et al. (2017) & Manappallil et al. (2019) & Index case \\
\hline Age (years) & 18 & 6 & 69 & 48 & 13 \\
\hline Gender & Male & Male & Male & Male & Male \\
\hline Premorbid illness & Nil & Nil & $\begin{array}{l}\text { Non-Hodgkin } \\
\text { lymphoma } 4 \text { years } \\
\text { back (treatment } \\
\text { completed) }\end{array}$ & $\mathrm{Nil}$ & Nil \\
\hline $\begin{array}{l}\text { Clinical features } \\
\text { suggestive of } \\
\text { dengue }\end{array}$ & $\begin{array}{l}\text { Fever, myalgia, } \\
\text { lethargy, } \\
\text { headache, and } \\
\text { gum bleeding }\end{array}$ & $\begin{array}{l}\text { Fever and } \\
\text { lethargy }\end{array}$ & $\begin{array}{l}\text { Fever, myalgia, } \\
\text { headache, joint } \\
\text { pain, and anorexia }\end{array}$ & Fever and myalgia & $\begin{array}{l}\text { Fever, myalgia, rash, } \\
\text { and joint pain }\end{array}$ \\
\hline $\begin{array}{l}\text { Duration of dengue } \\
\text { fever (days) }\end{array}$ & 6 & 8 & 8 & 5 & 5 \\
\hline Complications & Nil & Nil & Nil & $\begin{array}{l}\text { Microinfarcts in basal } \\
\text { ganglia }\end{array}$ & Nil \\
\hline $\begin{array}{l}\text { Hemoglobin (gm/ } \\
\quad \text { dL) }\end{array}$ & 15.8 & NA & 10.2 & 18 & 15.1 \\
\hline $\begin{array}{l}\text { Total leukocyte } \\
\text { count }\end{array}$ & 3,000/uL & 3,700/uL & 5,590/uL & 2,500/uL & 2,950/uL \\
\hline Total platelet count & 64,000/uL & 176,000/uL & 100,000/uL & 15,000/uL & 87,000/uL \\
\hline $\begin{array}{l}\text { Alanine } \\
\text { transaminase } \\
(\mathrm{IU} / \mathrm{mL})\end{array}$ & 170 & Normal & 55 & 224 & 53 \\
\hline $\begin{array}{l}\text { Serum creatinine } \\
(\mathrm{mg} / \mathrm{dL})\end{array}$ & 1.0 & Normal & 1.0 & Normal & 0.6 \\
\hline Serum electrolytes & Normal & Normal & Normal & Normal & Normal \\
\hline NS1 antigen & Positive & Positive & Negative & Positive & Positive \\
\hline Dengue IgM & Negative & Positive & Positive & Positive & Negative \\
\hline Coinfection & Nil & Nil & Nil & Nil & Nil \\
\hline Drugs & Not specified & $\begin{array}{l}\text { Intravenous } \\
\text { normal saline }\end{array}$ & $\begin{array}{l}\text { Intravenous normal } \\
\text { saline }\end{array}$ & $\begin{array}{l}\text { Intravenous normal } \\
\text { saline, paracetamol, } \\
\text { folic acid supplements, } \\
\text { and pantoprazole }\end{array}$ & $\begin{array}{l}\text { Intravenous normal } \\
\text { saline and oral } \\
\text { paracetamol }\end{array}$ \\
\hline Blood products & Nil & $\mathrm{Nil}$ & Nil & Nil & Nil \\
\hline
\end{tabular}


TABLE 2

Comparison of clinical and laboratory parameters in the later phase of illness (dengue-induced parkinsonism)

\begin{tabular}{|c|c|c|c|c|c|}
\hline Variable & Azmin et al. (2013) & Fong et al. (2014) & Bopethha et al. (2017) & Manappallil et al. (2019) & Index case \\
\hline $\begin{array}{l}\text { Onset of neurological } \\
\text { symptoms }\end{array}$ & Day 6 of illness & Day 9 of illness & Day 8 of illness & Day 4 of illness & Day 6 of illness \\
\hline $\begin{array}{l}\text { Features suggestive of } \\
\text { parkinsonism }\end{array}$ & $\begin{array}{l}\text { Bradykinesia, } \\
\text { bradyphonia, and } \\
\text { broad-based ataxic } \\
\text { gait }\end{array}$ & $\begin{array}{l}\text { Bradykinesia and } \\
\text { akinetic mutism }\end{array}$ & $\begin{array}{l}\text { Bradykinesia, } \\
\text { bradyphonia, } \\
\text { stooped posture, } \\
\text { broad-based gait, } \\
\text { expressionless } \\
\text { facies, and } \\
\text { cogwheel rigidity }\end{array}$ & $\begin{array}{l}\text { Cogwheel rigidity, } \\
\text { bradykinesia, and } \\
\text { resting tremor }\end{array}$ & $\begin{array}{l}\text { Bradykinesia, } \\
\text { bradyphonia, } \\
\text { shuffling gait, } \\
\text { mask-like facies, } \\
\text { and cogwheel } \\
\text { rigidity }\end{array}$ \\
\hline $\begin{array}{l}\text { Other neurological signs } \\
\text { and symptoms }\end{array}$ & $\begin{array}{l}\text { Cerebellar ataxia, right } \\
\text { brachial plexopathy, } \\
\text { and cranial neuropathy } \\
\text { (11,12 CN on the right } \\
\text { side) }\end{array}$ & $\begin{array}{l}\text { Encephalopathy } \\
\text { and intermittent } \\
\text { dystonia }\end{array}$ & Nil & $\begin{array}{l}\text { Delirium and } \\
\text { mutism }\end{array}$ & Nil \\
\hline $\begin{array}{l}\text { Gadolinium-enhanced } \\
\text { magnetic resonance } \\
\text { imaging brain findings }\end{array}$ & Normal & Normal & Normal & $\begin{array}{r}\text { Microinfarcts in } \\
\text { basal ganglia }\end{array}$ & Normal \\
\hline CSF examination & $\begin{array}{l}\text { Acellular, protein- } 55 \mathrm{mg} / \\
\mathrm{dL} \text { and sugar- } 45 \mathrm{mg} / \mathrm{dL} \\
\text { (blood sugar- } 97 \mathrm{mg} / \mathrm{dL} \text { ) }\end{array}$ & Normal & $\begin{array}{l}45 \text { cells/ul }(92 \% \\
\text { lymphocytes), rest } \\
\text { normal }\end{array}$ & $\begin{array}{l}3 \text { cells/uL, protein- } \\
35 \mathrm{mg} / \mathrm{dL} \text {, and } \\
\text { glucose } 60 \mathrm{mg} / \mathrm{dL}\end{array}$ & $\begin{array}{l}\text { Acellular, protein- } \\
34 \mathrm{mg} / \mathrm{dL}, \text { and } \\
\text { sugar- } 63 \mathrm{mg} / \mathrm{dL} \\
\text { (blood sugar-87 } \\
\mathrm{mg} / \mathrm{dL} \text { ) }\end{array}$ \\
\hline EEG & Not done & $\begin{array}{l}\text { Diffuse delta } \\
\text { slowing }\end{array}$ & $\begin{array}{l}\text { Evidence of } \\
\text { encephalitis }\end{array}$ & Not done & Normal \\
\hline Nerve conduction study & Unremarkable & Not done & Not done & Not done & Unremarkable \\
\hline Electromyography & $\begin{array}{l}\text { Chronic denervation } \\
\text { changes in the right } \\
\text { deltoid and the right } \\
\text { trapezius suggestive of } \\
\text { right brachial } \\
\text { plexopathy }\end{array}$ & Not done & Not done & Not done & Unremarkable \\
\hline ANA & Negative & Not done & Negative & Not done & Negative \\
\hline HIV & Negative & Not done & Negative & Negative & Negative \\
\hline Neurometabolic screen & Not done & Not done & Not done & Not done & Negative \\
\hline Serum ceruloplasmin & Not done & Not done & Not done & Not done & Normal \\
\hline $\begin{array}{l}\text { CSF autoimmune } \\
\text { encephalitis antibody } \\
\text { profile }\end{array}$ & Not done & Not done & Not done & Not done & Negative \\
\hline $\begin{array}{l}\text { Serum anti-dopamine } \\
\text { receptor } 2 \text { antibody }\end{array}$ & Not done & Not done & Not done & Not done & Negative \\
\hline $\begin{array}{l}\text { Repeat serum/CSF } \\
\text { dengue IgM }\end{array}$ & Positive & Not done & Positive & Not done & Positive \\
\hline $\begin{array}{l}\text { CSF neurotropic virus } \\
\text { PCR }\end{array}$ & Negative & Not done & Negative & Not done & Negative \\
\hline Levodopa + carbidopa & - & $\begin{array}{l}\text { No response to the } \\
5 \text {-day course }\end{array}$ & 400 mg/day & 100 mg/day & 200 mg/day \\
\hline Corticosteroid & $\begin{array}{l}\text { Methylprednisolone } \\
500 \mathrm{mg} \text { OD for } 3 \text { days }\end{array}$ & $\begin{array}{l}\text { Methylprednisolone } \\
\text { pulse followed by } \\
\text { intravenous } \\
\text { dexamethasone }\end{array}$ & - & $\begin{array}{l}\text { Dexamethasone } \\
8 \mathrm{mg} \text { q6-hourly } \\
\text { for } 5 \text { days }\end{array}$ & - \\
\hline Clinical improvement & 1 month & 7 weeks & 1 month & 2 weeks & 2 weeks \\
\hline Residual symptoms & $\begin{array}{l}\text { Weakness of right deltoid } \\
\text { and right infraspinatus }\end{array}$ & Nil & Nil & Nil & Nil \\
\hline
\end{tabular}

dengue infection are more prevalent in cases with secondary dengue infection. Non-neutralizing antibody-mediated or antibody-dependent enhancement is responsible for increased severity in secondary dengue infection. ${ }^{2}$ Recently, autoimmune encephalitis has been reported during the recovery from viral encephalitis, especially HSV encephalitis, causing secondary worsening like our case. ${ }^{7}$ Post-viral autoimmune herpes simplex encephalitis is sometimes associated with autoantibodies to $\mathrm{N}$-methyl-D-aspartate receptor or dopamine-2 receptor. ${ }^{8}$ Often it also presents with predominant movement disorders like chorea or dyskinesia. ${ }^{7}$

Of the four cases in the existing literature, three had a favorable response with intravenous corticosteroids. ${ }^{3-5,9}$
Although most of the previously reported cases have not been investigated extensively to rule out the possibility of autoimmune etiology, however, clinical features of all these cases resemble that of autoimmune encephalitis. So, a possibility of seronegative autoimmune encephalitis, presenting with predominant parkinsonian features, cannot be ruled out completely. Even the pathophysiology behind dengue encephalitis, or more aptly called dengue encephalopathy, also includes autoimmune phenomenon, apart from vasculopathy, dyselectrolytemia, and direct neurotrophic effect. ${ }^{1}$ Dengue encephalopathy usually occurs during the acute stage. Acute risk factors, such as prolonged shock, hypoxia, systemic or cerebral hemorrhages, and metabolic disturbances, usually predispose this entity. ${ }^{1}$ 
Cerebrospinal fluid analysis usually remains normal. Direct vascular damage to basal ganglia was only present in one of the four previous cases, leading to microinfarcts. All these findings together suggest that dengue-induced parkinsonism is an entity distinguished from dengue encephalopathy, which invariably occurs after the recovery of acute illness.

As described earlier, the existing literature suggests the role of both levodopa and corticosteroids in post-dengue parkinsonism. $^{3-5,9}$ But in our case, corticosteroids were not needed, as there was a favorable response to levodopa. Irrespective of the treatment modality used, parkinsonian features usually subsided within 2-7 weeks of the onset, and one of the four cases had residual sequelae due to other associated neurological complications. ${ }^{3-5,9}$

\section{CONCLUSION}

The aforementioned report and literature review intend to be aware of the clinicians regarding parkinsonism as an uncommon neurological complication of such a common arboviral infection such as DF. Especially in endemic countries, it is imperative to consider this cause in a child with acute onset parkinsonism. It is uncommon, yet completely treatable. Levodopa and corticosteroids are available therapeutic options for this entity.

Received January 16, 2020. Accepted for publication April 7, 2020.

Published online May 4, 2020.

Acknowledgment: The American Society of Tropical Medicine and Hygiene (ASTMH) assisted with publication expenses.
Disclosure: We confirm that we have read the Journal's position on issues involved in ethical publication and affirm that this report is consistent with those guidelines.

Authors' addresses: Prateek Kumar Panda and Indar Kumar Sharawat, Pediatric Neurology Division, Department of Pediatrics, All India Institute of Medical Sciences, Rishikesh, India, E-mails: drprateekpanda@ gmail.com and sherawatdrindar@gmail.com. Rishi Bolia and Yash Shrivastava, Department of Pediatrics, All India Institute of Medical Sciences, Rishikesh, India, E-mails: rishibolia@yahoo.co.in and dr.yash.2409@gmail.com.

\section{REFERENCES}

1. LiGH, Ning ZJ, Liu YM, LiXH, 2017. Neurological manifestations of dengue infection. Front Cell Infect Microbiol 7: 449.

2. Murthy JMK, 2010. Neurological complications of dengue infection. Neurol India 58: 581-584.

3. Azmin S, Sahathevan R, Suehazlyn Z, Law ZK, Rabani R, Nafisah WY, Tan HJ, Norlinah MI, 2013. Post-dengue parkinsonism. BMC Infect Dis 13: 179-182.

4. Fong CY, Hlaing CS, Tay CG, Ong LC, 2014. Post-dengue encephalopathy and parkinsonism. Pediatr Infect Dis J 33: 1092-1094.

5. Bopeththa BVKM, Ralapanawa U, 2017. Post encephalitic parkinsonism following dengue viral infection. BMC Res Notes 10: 655-658.

6. Jang H, Boltz DA, Webster RG, Smeyne RJ, 2009. Viral parkinsonism. Biochim Biophys Acta 1792: 714-721.

7. Leypoldt $F$ et al., 2013. Herpes simplex virus-1 encephalitis can trigger anti-NMDA receptor encephalitis: case report. Neurology 81: 1637-1639.

8. Chaudhary H, Kasinathan A, Sharawat IK, Saini AG, Mahadevan A, Sankhyan N, 2018. Post-herpetic autoimmune encephalitis. Indian J Pediatr 85: 691-692.

9. Manappallil RG, 2019. Parkinsonism following basal ganglia infarction in Dengue fever. Asian J Med Sci 10: 62-64. 